\title{
Sistemas de desmame precoce e fertilidade pós-parto em vacas de corte suplementadas com gestágeno*
}

\author{
HOMERO GUILLERMO QUINTELA BAZZANO
}

\author{
José Carlos Ferrugem Moraes (Orientador - UFRGS)
}

Banca: José Carlos Ferrugem Moraes (UFRGS), Rodrigo Costa Mattos (UFRGS), Claudio Alves Pimentel (UFPel), Marcelo Alves Pimentel (UFPel)

A fertilidade das vacas com cria ao pé é uma característica importante para os sistemas de produção de bovinos de corte. Considerando esse fato, o alvo deste estudo foi avaliar a fertilidade pós-parto de vacas de corte, submetidas a diferentes condições de: aleitamento, suplementação hormonal, condição corporal, período pós-parto e estação de acasalamento. Com esses objetivos foram efetuados quatro experimentos, avaliando o efeito da suplementação com progestágeno na fertilidade de vacas de corte paridas no outono e desmamadas entre 45-75 dias pós-parto; o momento da suplementação com progestágeno em vacas de corte paridas na primavera e desmamadas entre 60-81 dias pós-parto; a suplementação com progestágeno associada à desmame total e parcial em função da condição corporal aos 60-81 dias pós-parto e a eficiência do desmame temporário ou aleitamento uma vez ao dia em vacas de corte submetidas a suplementação com progestágeno. Foram analisados dados de freqüência de manifestação de cios e de prenhez nos quatro experimentos. Os resultados obtidos indicaram que: a suplementação com progestágeno não melhorou a fertilidade de vacas de corte paridas no outono e desmamadas entre 45-75 dias pós-parto, o fator fundamental na fertilidade de vacas paridas no outono foi a condição corporal que deve ser no mínimo CC4 (numa escala de 1-5); a suplementação com progestágeno em vacas de corte paridas na primavera e desmamadas entre 60-81 dias pós-parto viabiliza o uso da inseminação artificial e contribui para a obtenção de bons resultados reprodutivos em vacas com CC igual ou superior a CC3; a suplementação com progestágeno associada a desmame durante 96 horas em vacas com $\geq$ CC3 é uma alternativa viável para incrementar a taxa de prenhez após monta natural ou inseminação artificial em vacas com cria ao pé; é possível inferir que a eficiência reprodutiva de vacas de corte pós-parto submetidas a suplementação com progestágeno e desmame temporário ou aleitamento uma vez ao dia tenham desempenho semelhante, porém são necessários outros estudos. De um modo geral os experimentos efetuados sugerem que é necessário estabelecer um equilíbrio entre oferta e demanda forrageira, ao longo do ano, que possibilite uma máxima percentagem de vacas em CC adequada no começo do serviço, considerando a época de acasalamento, momento pós-parto, suplementação hormonal além da modalidade de desmame, visando a obtenção da máxima produção de kg de carne/superfície/tempo e considerando as condições de ambiente.

Descritores: vaca de corte, fertilidade, progestágeno, pós-parto, desmame. 


\title{
Systems of precocious weaning and postpartum fertility in beef cow ${ }^{* *}$
}

\author{
HOMERO GUILLERMO QUINTELA BAZZANO
}

José Carlos Ferrugem Moraes (Adviser - UFRGS)

Committee: José Carlos Ferrugem Moraes (UFRGS), Rodrigo Costa Mattos (UFRGS), Claudio Alves Pimentel (UFPel), Marcelo Alves Pimentel (UFPel)

The post-partum fertility of suckling beef cows is an important economic characteristic for bovine production. The objective of this study was to evaluate the postpartum fertility of suckling cows, submitted to different conditions of: weaning, hormonal supplementation, corporal condition, postpartum interval and breeding season. With those objectives four experiments were made to evaluate the effect of the supplementation with progestagen in the fertility of beef cows given birth in the autumn and weaned from 45 to 75 days postpartum; the moment of the supplementation with the progestagen in cows that calved in spring and weaned from 60 to 81 days postpartum; the supplementation with progestagen associated to depend weaning or for 96 hours in function of the body condition 60-81 days postpartum and finally the efficiency of the temporary weaning in comparison to once a day suckling in cows submitted the supplementation with progestagen. Data of estrous frequency and pregnancy rates in the four experiments were analyzed. The results showed that: the supplementation with the progestagen did not improve fertility of cows that calved in the autumn, and weaned 45-75 days postpartum, the most factor in fertility of cows calved in autumn was the body condition that must be at least CC4 (in a scale of 1-5); the supplementation with progestagen in cows that calved in spring and weaned between 60-81 days postpartum allows the use of the artificial insemination and contributes to obtain good reproductive results when $\mathrm{CC}$ was equal or superior to $\mathrm{CC} 3$; the supplementation with progestagen in cows weaned for 96 hours with $\geq \mathrm{CC} 3$ is a viable alternative to increase pregnancy rate under natural mating or artificial insemination in suckling cows; it was not possible to detect effect of progestagen on reproductive efficiency of postpartum cows submitted to progestagen, temporary weanning or suckling once a day they efficiency of postpartum cows. The results suggest that is necessary to set equilibrium among offer and demands of forages along the year. That makes possible a higher percentage of cows in CC3 at the beginning of the breeding season, considering the postpartum interval and hormonal treatment besides the type of weaning, seeking the obtaining of the maximal production of meat/area/time and considering the production conditions.

Key words: beef cow, fertility, progestagen, postpartum, weaning. 